\title{
Strategic development priorities of safety standards and business models of the hospitality industry in the conditions of restrictions and post-Covid period (by the example of St. Petersburg)
}

Olga Arkhipova*, Svetlana Stepanova, Andrey Nikolaev, Tatyana Bedyaeva, and Natalya Fomicheva

Saint Petersburg State University of Economics, 21 Sadovaya St., 191023 St. Petersburg, Russia

\begin{abstract}
This article covers the issue of determining new standards of tourist and hotel business, including safety in new realities formed under the influence of novel coronavirus infection. The authors provide research results representing strategic development priorities of safety standards and business models of hotel business of St. Petersburg in the conditions of restrictions and post-Covid period.
\end{abstract}

\section{Problem statement}

In 2020-2021, the Department of Hotel and Restaurant Business of the Saint Petersburg State University of Economics conducted research aimed at determining new standards of tourist, hotel and restaurant business, including safety in new realities formed under the influence of novel coronavirus infection. We provide the results representing strategic development priorities of safety standards and promising business models of tourist and hotel business of St. Petersburg in the conditions of restrictions and post-Covid period.

\section{Key research results}

It is found out that differentiation of service practices oriented towards ensuring guests safety at the hotel facility takes place in the conditions of the pandemic. Development and distribution of safety protocols and programs promote for development of a list of necessary operations, i.e. universalization of standards of staff activity. In the network hotels, this process goes quicker since the hotels of this class had such practice before the pandemic. The protocols for residential and public areas of hotels and safety protocols are actively adopted and used by $5-4^{*}$ hotels as they orient towards foreign tourists, before the pandemic, these hotels had a common practice to orient towards global trends considered to be must-have features of their image. The situation looks more difficult for local mid-range and economy hotels, as well as apart-hotels. Nevertheless, they also must meet the

\footnotetext{
* Correspondent author: olva@list.ru
} 
requirements of the Federal Service for the Oversight of Consumer Protection and Welfare in the conditions of the pandemic. In other words, the universalization of corporate business standards and processes in the hotel infrastructure takes place in the legislative framework. Along with this, a number of the world branded hotels switched over to mobile standards by using mobile applications that allows to expand staff adaptation, create conditions for flexible operation with internal standards in the ever-changing situation.

Contactless service in hotels has become a reality, a number of hotels had promoted such programs even before the pandemic that ensured their leading positions. The key players in the global market in 2020 irrespective of the pandemic are: Marriott International, InterContinental Hotels Group, AccorHotels [1; 2]. The next stage to develop and use in hotel promotion of the interactive self-isolation ending charts and VR- and AR technologies that will be probably considered a prerequisite for guest comfort after the pandemic ends. Such technologies provide for ensuring personalization of wishes of a guest that had been much spoken of before the pandemic [3].

As to the Russian hotels, it should be noted that switching over to operational processes with the use of digital technologies is somewhat decelerated due to the anti-Covid measures from March till June 2020. The conservative thinking of hoteliers is also not the least of the factors hindering switch-over to and implementation of digital technologies. In this case, the COVID pandemic can serve as a sort of stress test and a catalyst for speeding up the switch-over to new digital technologies [4].

Using the methods of expert assessment made it possible to forecast the development of hotel facilities by key performance indicators for 2020-2021. The obtained results provide for making a conclusion that the midscale hotel facilities, apart hotels and country hotels will be in demand in the short-term period. As to the $4 *$ hotels as the most mass ones, the analysts think that the occupancy will be within $44-42 \%$, and according to the most favourable forecast, it will reach its maximum in June and make $84 \%$, and will not exceed $56 \%$ in average for 2021 . As to the $3 *$ hotels, the occupancy will be within $64 \%$, and according to the most favourable forecast, it will reach its maximum in June and make $96 \%$, and will not exceed $74 \%$ in average for 2021 [5].

Thus, on the strength of all the data received by different research methods, it can be summarized as follows:

the differentiated parameters show their relevance: safety, functions and internal standards of the hotel facility, digitalization and contactless services, change of the hotel target audience, staff;

$>\quad$ the necessity in changing professional and corporate standards and appearance of new formats to regulate activities of top management and staff of hotels have been proved;

$>\quad$ the digital and contactless services are being actively implemented in the conditions of the pandemic;

the midscale hotel facilities, apart hotels and country hotels will remain in demand in the short-term period, that's why it is necessary to develop support and promotion program for this hotel segment.

\section{Key trends to building business models for tourism and hospitality industry in the conditions of restrictions and post- Covid period}

The next step of the research was to determine the short-term and long-term trends to building business models for the tourism and hospitality industry in the conditions of restrictions and post-Covid period. We have used the scenario approach in this work. Three 
key scenarios of the situation have been considered, and the most promising business models of tourist and hotel business developed in the course of expert sessions and focus groups by a team of researchers have been offered in the framework of each scenario.

Scenario No. 1. Preservation of entry restrictions for foreign tourists and partial restrictions for domestic tourists for holding the events, work of cafés and restaurants, hotels (strategy for cash flow maintenance and cost minimization).

In the framework of Scenario No. 1, the business models for hotel facilities should take into account the current consumer strategies with minimum staff interference with the servicing process [6].

In the framework of Scenario No. 1, the following parameters were determined in business process modelling for the hotel industry:

- $\quad$ system changes in the hotel industry;

- $\quad$ changes in the operational activity of hotels and other accommodation facilities;

- $\quad$ staff changes.

The following problem areas on the above parameters have been determined on the evidence basis for the development of recommendations:

1.1 System changes in the hotel industry, problem areas:

- field-specific structure of hotel business of St. Petersburg has changed: country and apart hotels have gained priority in the conditions of pandemic and their occupancy has made $30 \%$; inquiries for resort hotels have increased by $7 \%$, for $5^{*}$ hotels by $41 \%$; therefore, the differentiation between the "personalized" accommodation facilities and mass economy class $(4-3 *)$ has increased;

reduced occupancy: for international network hotels in Q2 2020, it has made $5.2 \%$, and for others - from 3 to $7 \%$;

- $\quad$ suspension of operations of hotels (bankruptcy and closing of hotels);

- $\quad$ change in target audience: business tourists switch over to online.

Recommendations for the parameter of system changes in the hotel industry:

A. monitoring of key performance indicators of hotels (ADR, RevPAR, Occupancy), creation of the "dynamic pricing" platform for prompt information of hoteliers and establishing "weighted" prices; option;

B. restructuring of no-star, 1-3* hotels: long-term renting of room inventory as an

C. roadmap development for comprehensive promotion of local $4-5^{*}$, resort and conceptual hotels that form the image of the city.

1.2 Operational activity of hotels and accommodation facilities, problem areas:

- $\quad$ service provision; difficult collaboration, "breakdown" of the traditional process

chain;

ensuring quality service; scattered staff, thus, difficulty in ensuring the required communication quality, actual reduction in housekeeping service and other staff reduction.

Recommendations for the parameter of operational activity of hotels and accommodation facilities:

A. change in servicing with due regard to customer and staff safety by using new sanitary standards, correction of the staff work regulations: cleanliness maintenance protocols, compliance with sanitary requirements and social distance;

B. change in service cycle - minimization of contacts between guests and staff: change of public spaces of hotels; flexible online booking; early check-in;

C. adaptation of the staff work to the potentially growing inquiries from customers (for example, on booking cancellation); staff reorientation to online services using the one contact technology.

1.3 Staff changes and problem areas:

- $\quad$ maintaining the staff and proving the jobs and salary; 
ensuring staff and guests' safety; change in the interior of public areas and staff rooms; use of disinfectants and sanitizers, creation of isolation units, disinfection of entry and exit zones for the staff.

Recommendations for the parameter of staff changes in hotels and accommodation facilities:

A. staff work optimization: staff regrouping and switching over to team work (Project Management), each team member becomes universal and performs various functions; the alternative option is to assign some staff who ensure hotel operation, and transfer the others to remote work;

B. creation of staff and training platforms for the staff operational and remote adaptation to new standards.

Therefore, on the basis of Scenario No. 1 and the above information, the business model "Hospitality: Safe Standard" can be offered that provides minimum staff interference with the servicing process: safety - mobile standards - mobile staff - services in the VR and AR format (Figure 1).

\begin{tabular}{|c|c|c|c|c|c|}
\hline \multirow{2}{*}{$\begin{array}{l}\text { Participants } \\
\text { and } \\
\text { Partners } \\
\text { Hotels } \\
\text { Specialized } \\
\text { accommodati } \\
\text { on facilities } \\
\text { Food and } \\
\text { Beverage } \\
\text { Associations } \\
\text { and units in } \\
\text { tourist, hotel } \\
\text { and } \\
\text { restaurant } \\
\text { business }\end{array}$} & $\begin{array}{l}\text { Value offers } \\
\text { Improved } \\
\text { safety, } \\
\text { virtual } \\
\text { services, staff } \\
\text { adaptedness } \\
\text { and mobility }\end{array}$ & \multicolumn{2}{|c|}{$\begin{array}{l}\text { Items of } \\
\text { cooperation } \\
\text { Monitoring of key } \\
\text { performance } \\
\text { indicators of } \\
\text { accommodation } \\
\text { facilities and food } \\
\text { and beverage, } \\
\text { creation of the } \\
\text { "dynamic pricing" } \\
\text { platform }\end{array}$} & $\begin{array}{l}\text { Key messages for } \\
\text { the target audience: } \\
\text { Safety, new service } \\
\text { standards - } \\
\text { contactless } \\
\text { services, } \\
\text { smart management } \\
\text { of the room }\end{array}$ & \multirow[t]{2}{*}{$\begin{array}{l}\text { Target audience } \\
\text { Residents of St. } \\
\text { Petersburg and } \\
\text { Leningrad region, } \\
\text { domestic visitors } \\
\text { of the city and } \\
\text { region, } \\
\text { population groups } \\
\text { with mixed age, } \\
\text { especially of the } \\
\text { 2000s generation }\end{array}$} \\
\hline & \multicolumn{2}{|c|}{$\begin{array}{l}\text { Resources: } \\
\text { Financial, materials and } \\
\text { equipment, staff }\end{array}$} & \multicolumn{2}{|c|}{$\begin{array}{l}\text { Media promotion channels } \\
\text { Internet advertising, social } \\
\text { networks, } \\
\text { exhibitions, business MICE } \\
\text { events, mass media. }\end{array}$} & \\
\hline \multicolumn{2}{|c|}{$\begin{array}{l}\text { Product organization expenses: } \\
\text { - reorganization expenses of the } \\
\text { facility } \\
\text { - expenses for new and unique } \\
\text { offers promotion } \\
\text { - expenses for digital technology } \\
\text { implementation }\end{array}$} & \multicolumn{2}{|c|}{$\begin{array}{l}\text { Income flows and } \\
\text { potential } \\
\text { investors } \\
\text { - reserve funds of } \\
\text { participants and } \\
\text { partners } \\
\text { - funds of tourists } \\
\text { and service } \\
\text { consumers }\end{array}$} & \multicolumn{2}{|c|}{$\begin{array}{l}\text { Key effects } \\
\text { - restructuring of accommodation } \\
\text { facilities } \\
\text { - service market promotion of } \\
\text { accommodation facilities } \\
\text { - improved safety due to contactless } \\
\text { services and digital technology } \\
\text { implementation }\end{array}$} \\
\hline
\end{tabular}

Fig. 1. Business Model "Hospitality: Safe Standard"

Scenario No. 2. Gradual lifting of restrictions on the entry of foreign tourists and partial restrictions for domestic tourists, as well as restrictions on holding the events (strategy for cash flow maintenance and cost minimization).

In the framework of Scenario No. 2, in case of gradual lifting of restrictions on the entry of foreign and domestic tourists:

- $\quad$ introduction of new digital standards and safe business standards promotes for attracting foreign and domestic tourists that will allow to increase the return of tax and duties to the regional budget;

development of digital personalized technologies to improve the safety of foreign and domestic tourists; 
- $\quad$ maintained trend to optimize the work of the hotel staff by combining remote and traditional work formats.

2.1. System changes in the hotel industry, problem areas:

- increased occupancy: at the expense of the tourists from the Asian region as the most probable option

- $\quad$ change in field-specific structure: increased role of the mid-price segment with the introduction of new sanitary and epidemiological standards;

- increased demand for individual accommodation facilities and alternative housing: for the short period of the lifting of restrictions in July-August, the number of inquiries for these accommodation facilities achieved the 2019 level and made $33.2 \mathrm{mln}$. as compared to 2019, i.e. $33.4 \mathrm{mln}$. (see the research by Yandex "Tourism in Summer 2020")

Recommendations for the parameter of system changes in the hotel industry:

A. update of "Friendly" programs considering new safety standards;

$B$. creation of integrated booking and reservation platforms for collective, individual accommodation facilities and rental of alternative housing for the Asian tourists;

2.2. operational activity of hotels and accommodation facilities, problem areas:

- service provision: renewal of collaboration in-house, with suppliers, partners, customers;

- $\quad$ service provision with the use of digital technology: change in the work of the following departments: Front Office, Room Inventory Department, Commercial Department, Booking Department, PR Department, etc.:

- ensuring staff and guests' safety; along with the use of disinfectants and sanitizers, personal data safety and financial safety of guests and staff in the conditions of contactless services.

Recommendations for the parameter of operational activity of hotels and accommodation facilities:

A. enhanced understanding of the staff and guests' safety: ensuring personal and financial safety due to flexible and new service standards; creation of mobile applications educational platforms for staff training in new standards and regulations, cleanliness maintenance protocols;

$B$. change in service cycle - additional income receipt: online booking platform; mobile receptionist in life streaming mode - the hotel staff becomes available any time $(76.9 \%$ of respondents consider it necessary to implement digital technology and develop new digital standards since this improve the hotel safety, and thus, promotes for attracting foreign tourists).

2.3 Staff changes and problem areas:

- $\quad$ staff coordination considering remote work, freelancer and outsourcing;

- $\quad$ ensuring staff and guests' safety; change in the interior of public areas and staff rooms; disinfection of entry and exit zones for the staff.

Recommendations for the parameter of staff changes in hotels and accommodation facilities:

A. development of new standards considering the sanitary and epidemiological situation and groups of tourists, the mobile transmission of new standards through training platforms (according to the survey data, $40 \%$ of hotels use training platforms, the others, i.e. over $40 \%$, use mobile applications and chat-bot);

B. staff work optimization - minimization of direct contacts, if necessary, creation of isolation units for the staff in staff rooms;

C. mobile staff: universalization of corporate standards to adapt to the hotel work, creation of the unified database for a selection of operating personnel and engagement on a self-employment basis; 
D. creation of staff and training platforms for the staff operational and remote adaptation to new standards.

Thus, on the basis of Scenario No. 2, the business model "Hospitality: Digital Services" can be offered that is oriented towards the development of personalized technologies and optimization of hotel staff work by using digital technology, combined online and offline work when providing main and additional services (Figure 2).

\begin{tabular}{|c|c|c|c|c|c|c|}
\hline \multirow[t]{2}{*}{$\begin{array}{l}\text { Participants and } \\
\text { Partners } \\
\text { Hotels } \\
\text { Specialized } \\
\text { accommodation } \\
\text { facilities } \\
\text { Food and Beverage } \\
\text { IT companies }\end{array}$} & \multicolumn{2}{|c|}{$\begin{array}{l}\text { Value offers } \\
\text { Openness and } \\
\text { versatility of } \\
\text { digital standards } \\
\text { and safety } \\
\text { standards, } \\
\text { in-house } \\
\text { collaboration }\end{array}$} & \multicolumn{2}{|c|}{$\begin{array}{l}\text { Items of } \\
\text { cooperation } \\
\text { Mobile, } \\
\text { universal } \\
\text { standards, } \\
\text { staff and training } \\
\text { platforms }\end{array}$} & $\begin{array}{l}\text { Key messages } \\
\text { for the target } \\
\text { audience: } \\
\text { Safety and } \\
\text { financial } \\
\text { stability }\end{array}$ & \multirow{2}{*}{$\begin{array}{l}\text { Target } \\
\text { audience } \\
\text { Guests from } \\
\text { the Asian } \\
\text { region, } \\
\text { domestic } \\
\text { tourists, } \\
\text { population } \\
\text { groups with } \\
\text { mixed age }\end{array}$} \\
\hline & \multicolumn{3}{|c|}{$\begin{array}{l}\text { Resources: } \\
\text { Financial, materials and } \\
\text { equipment, staff resources }\end{array}$} & \multicolumn{2}{|c|}{$\begin{array}{l}\quad \text { Media promotion } \\
\text { channels }\end{array}$} & \\
\hline \multicolumn{2}{|c|}{$\begin{array}{l}\text { Product organization } \\
\text { expenses: } \\
\text { - reorganization expenses of } \\
\text { the facility } \\
\text { - expenses for new and } \\
\text { unique offers promotion } \\
\text { - expenses for digital } \\
\text { technology implementation }\end{array}$} & \multicolumn{3}{|c|}{$\begin{array}{l}\text { Income flows and potential } \\
\text { investors } \\
\text { - reserve funds of } \\
\text { participants and partners } \\
\text { - funds of tourists and } \\
\text { service consumers } \\
\text { - grant support by } \\
\text { foundations }\end{array}$} & \multicolumn{2}{|c|}{$\begin{array}{l}\text { Key effects } \\
\text { - development of new standards } \\
\text { considering the sanitary and } \\
\text { epidemiological situation and } \\
\text { groups of tourists } \\
\text { - mobile transmission of new } \\
\text { standards through training } \\
\text { platforms } \\
\text { - promotion of food delivery by } \\
\text { food and beverage }\end{array}$} \\
\hline
\end{tabular}

Fig. 2. Business Model "Hospitality: Digital Services"

Scenario No. 3. Up-and-down development of the COVID-19 pandemic that is characterized by strengthening sanitary and epidemiological measures (strategy for quick adaptation to the situation with minimum turnover maintained).

The up-and-down development of the COVID-19 pandemic requires new safety standards, universalization of corporate business standards and processes in the hotel infrastructure:

financial stability of tourist, hotel and restaurant facilities will be a critical success factor for the industry in the up-and-down development of the pandemic due to inter-industry and intra-industry collaboration;

- particular attention should be paid to the development and rendering of flexible and universal standards to consolidate the business in terms of the service implementation with the use of digital technology and staff work optimization;

change in the service cycle should be accompanied by consumers' and staff safety and switch-over to the project management with the use of flexible personalized technologies.

\subsection{System changes in the hotel industry, problem areas:}

the financial instability of hotel business caused by fluctuations in occupancy: from $3 \%$ to $84 \%$ for $4 *$ hotels and $96 \%$ for $3 *$ hotels; suspension of operations of hotels and closing of profitless hotels - to $30 \%-40 \%$; 
change in field-specific structure: increase in individual accommodation and alternative rental; extensive use of digital technology changing the service cycle and beliefs about service quality.

Recommendations for the parameter of system changes in the hotel industry:

A. creation of investment reserve fund:

- $\quad$ for development of hotel efficient promotion programs and loyalty programs oriented towards individual tourists;

- $\quad$ for restructuring of profitless hotels and long-term renting of room inventory.

$B$. development and rendering of flexible and universal standards for hotels, individual accommodation facilities and alternative housing to ensure safe accommodation of foreign tourists (including those from the Asian region) and domestic tourists.

C. inter-industry and intra-industry collaboration of hospitality, tourist facilities, transport and industrial companies.

3.2 Operational activity of hotels and accommodation facilities, problem areas:

- $\quad$ service provision: collaborations in the framework of inter-industry and intraindustry consortium;

service provision with the use of digital technology: integrated work of all departments, optimization of standards and protocols by using mobile applications, change in the hotel accommodation procedure;

- $\quad$ ensuring staff and guests' safety; along with the use of disinfectants and sanitizers, personal data safety and financial safety of guests and staff in the conditions of contactless services.

Recommendations for the parameter of operational activity of hotels and accommodation facilities:

A. development of a roadmap and typical agreement on inter-industry cooperation of hotels and travel companies;

$B$. improved safety - implementation of technical solutions for contactless check-in in alternative housing, placement of information about long-term rental of room on the Internet platform; development of compatible integrated safety protocols;

C. change in service cycle: class;

$$
\text { simplified hotel/guest interaction, use of digital products of smart check-in }
$$

- $\quad$ use of voice assistants and navigators in the course of service provision; digital technology;

reduced costs for preparation of regulations and staff training due to the use of

- business promotion with the use of the interactive self-isolation ending charts, virtual and augmented reality.

3.3 Staff changes and problem areas:

- $\quad$ staff coordination considering remote work, freelancer and outsourcing [7];

- $\quad$ staff safety when working in the contact zone: change in the interior of staff rooms with the use of disinfectants and sanitizers; accommodation facilities:

Recommendations for the parameter of staff changes in hotels and

A. new professional standards: in the course of the survey, $51.8 \%$ of respondents noted the necessity to develop new professional standards that should include two main components: flexibility, variability considering the sanitary and epidemiological situation and versatility of standards considering competencies of a specialist in the specialized product creation;

B. staff work optimization - switch-over to team work (Project Management) with the use of flexible technologies, minimization of direct contacts, if necessary, creation of isolation units for the staff in staff rooms; 
C. mobile staff: universalization of corporate standards to ensure quick adaptation of the staff to the hotel work, creation of the unified database for a selection of operating personnel and engagement on a self-employment basis; creation of staff and training platforms for the staff operational and remote adaptation to new standards.

Thus, on the basis of Scenario No. 3, the business model "Hospitality: Universal Standard" can be offered that is oriented towards the development of universal and flexible standards, inter-industry and intra-industry collaboration to create single point representation and ensure staff and guests' safety with due regard to their digital personalized needs (Figure 3).

\begin{tabular}{|c|c|c|c|c|c|}
\hline \multirow[t]{2}{*}{$\begin{array}{l}\text { Participants and } \\
\text { Partners } \\
\text { Hotels } \\
\text { Specialized } \\
\text { accommodation } \\
\text { facilities } \\
\text { Food and Beverage } \\
\text { IT companies } \\
\text { Associations and } \\
\text { units in tourist and } \\
\text { hotel business. }\end{array}$} & \multicolumn{2}{|c|}{$\begin{array}{l}\text { Value offers } \\
\text { Financial stability, } \\
\text { improved safety, } \\
\text { inter-industry and } \\
\text { intra-industry } \\
\text { collaboration }\end{array}$} & \multicolumn{2}{|c|}{$\begin{array}{l}\text { Items of cooperation } \\
\text { Monitoring of key performance } \\
\text { indicators } \\
\text { Diversification of restaurant } \\
\text { business Development of Dark } \\
\text { Kitchens format } \\
\text { Long-term renting of room } \\
\text { inventory } \\
\text { Update of "Friendly" programs } \\
\text { Creation of integrated booking } \\
\text { and rental platforms for } \\
\text { alternative housing }\end{array}$} & \multirow[t]{2}{*}{$\begin{array}{l}\text { Target } \\
\text { audience } \\
\text { Foreign and } \\
\text { domestic } \\
\text { visitors of the } \\
\text { city and region, } \\
\text { population } \\
\text { groups with } \\
\text { mixed age }\end{array}$} \\
\hline & \multicolumn{3}{|c|}{$\begin{array}{l}\text { Resources: } \\
\text { Financial, materials and } \\
\text { equipment, staff resources, } \\
\text { industrial business } \\
\text { investments }\end{array}$} & \begin{tabular}{l}
\multicolumn{1}{c}{$\begin{array}{c}\text { Media promotion } \\
\text { channels }\end{array}$} \\
Internet advertising, \\
social networks, \\
business MICE events
\end{tabular} & \\
\hline \multicolumn{2}{|c|}{$\begin{array}{l}\text { Product organization } \\
\text { expenses: } \\
\text { - reorganization expenses of } \\
\text { the facilities } \\
\text { - expenses for promotion of } \\
\text { new forms and } \\
\text { implementation of digital } \\
\text { technologies }\end{array}$} & \multicolumn{2}{|c|}{$\begin{array}{l}\text { Income flows and } \\
\text { potential investors } \\
\text { - reserve funds of } \\
\text { participants and partners } \\
\text { - funds of tourists and } \\
\text { service consumers } \\
\text { - grant support by } \\
\text { foundations }\end{array}$} & \multicolumn{2}{|c|}{$\begin{array}{l}\text { Key effects } \\
\text { - restructuring of accommodation } \\
\text { facilities } \\
\text { - legalization of real estate market in } \\
\text { terms of long-term lease } \\
\text { - service market promotion for } \\
\text { similar accommodation facilities } \\
\text { - Development of Dark Kitchens } \\
\text { format }\end{array}$} \\
\hline
\end{tabular}

Fig. 3. Business Model "Hospitality: Universal Standard"

\section{Conclusion}

Therefore, the tourism market and hotel business in St. Petersburg in the conditions of COVID related challenges can be developed according to two scenarios:

Scenario No. 1: Preservation of restrictions on entry for foreign tourists and partial restrictions for domestic tourists for holding the events, work of cafés and restaurants, hotels, creative spaces, facilities of tourist and excursion interest until 2022.

Scenario No.2: Gradual lifting of restrictions on the entry of foreign tourists and partial restrictions for domestic tourists, as well as restrictions on holding the events by January 2022.

It should be noted that Scenario No. 3 remains possible: Up-and-down development of the COVID-19 pandemic that is characterized by strengthening sanitary and epidemiological measures (strategy for quick adaptation to the situation with minimum turnover maintained). 


\section{References}

1. Hotels After Coronavirus: What Happens After a Pandemic, Https://www.plugandplaytechcenter.com/

2. Upselling During a Pandemic: Early Check-In and Late Check-Out, https://www.hospitalitynet.org/

3. M.D. Trofimova, V.G. Gerasimova, Plekhanov Russian University of Economics, 5, 21 (2019)

4. Hotel won't make allowances for the pandemic. Large-scale digitalization has become a problem for lossmaking sector, https://www.ng.ru

5. Statistics and Analytics of Hotel Business, https://umhos.ru/

6. O.V. Arkhipova, Hotel business management: transformation, new resources and opportunities, 149 (2020)

7. O.V. Arkhipova, A.L. Zelezinsky, T. Maurer, Economic Vector, 4(23), 5 (2020)

8. Bare figures: operational performance of hotel segment 2020, https://www.cafefuture.ru 